\title{
BACTERIOLOGICAL AND PHYSICOCHEMICAL QUALITY OF SOME WATER BOREHOLES IN EKOSODIN, BENIN CITY, NIGERIA
}

\author{
Qualidade bacteriológica e físico-química da água de \\ poços em Ekosodin, Benin, Nigéria
}

Solomon Henry Agbon Aluyi ${ }^{1}$

Frederick Osaro Ekhaise ${ }^{2}$

Basil Nevol

\begin{abstract}
The Bacteriological and physicochemical quality of five (5) boreholes (Ikoyi's lodge, Newton's Villa, Iyobosa Hostel, Embassy Hostel and Amega Villa) in Ekosodin village were investigated fortnightly, from March 2004 - July 2004. The bacteriological analysis showed low counts of total heterotrophic and potential human pathogenic bacteria that ranged from $1.0 \times 10^{1} \mathrm{cfu} / \mathrm{mI}-3.1 \times 10^{1} \mathrm{cfu} / \mathrm{mI}$, and $0.0-1.9 \times 10^{1} \mathrm{cfu} / \mathrm{mI}$ respectively. Total coliform counts with MPN values ranged from $0.00 \mathrm{MPN} / 100 \mathrm{mI}-9 \mathrm{MPN} / 100 \mathrm{mI}$. E coli occurred occasionally in stations 2,3 and 5 with a range of $0.00 \mathrm{MPN} / 100 \mathrm{mI}-4 \mathrm{MPN} / 100 \mathrm{mI}$. Streptococcus faecalis was observed only in station 3, Clostridium perfringens was not detected in any of the sampled stations. Other organisms isolated and characterized during the study included Staphylococcus aureus and Proteus sp. Some of the physicochemical parameters studied included water temperature, conductivity, $\mathrm{pH}$, total suspended solids, and total dissolved solids. All had low mean concentrations that ranged from $27.0^{\circ} \mathrm{C}$ $-28.0^{\circ} \mathrm{C} ; 9.2-13.6 \mathrm{us} / \mathrm{cm}, 6.4-6.7 ; 0.06-0.08 \mathrm{mg} / \mathrm{l}$ and $0.15-0.20 \mathrm{mg} / \mathrm{l}$ respectively. The biological oxygen demand (BOD), dissolved oxygen (DO), total alkalinity and total hardness in $\mathrm{mg} / \mathrm{l}$ were all low and ranged from $0.08 \mathrm{mg} / 1-0.2 \mathrm{mg} / 1 ; 0.7 \mathrm{mg} / 1-1.0 \mathrm{mg} / 1 ; 5.0 \mathrm{mg} / 1-6.0 \mathrm{mg} / 1$ and $0.10 \mathrm{mg} / 1-0.13 \mathrm{mg} / 1$ respectively. Other parameters with low concentration were nitrate $(0.05-0.11 \mathrm{mg} / \mathrm{l})$, sulphate, $(0.07 \mathrm{mg} / 1-0.13 \mathrm{mg} / \mathrm{l})$ and phosphate $(0.0 \mathrm{mg} / \mathrm{l}-0.10 \mathrm{mg} / \mathrm{l})$. All the physicochemical parameters considered did not indicate any possible physicochemical pollution as they all fell within the (9) maximum permissible level for portable water. There were both positive and negative correlations between some of the bacteriological and physicochemical properties at a significant level of 95\% probability limit. Based on the bacteriological and physicochemical parameters studied, boreholes 1 and 4 are fit for direct consumption, while bore holes 2 , 3 and 5 failed to meet the bacteriological standard for portable water.
\end{abstract}

Keywords: Bacteriological and physicochemical quality; Ekosodin; E coli; Streptococcus faecalis; Staphylococcus aureus; Boreholes.

Researchers from Department of Microbiology, Faculty of Science, University of Benin City, Nigeria. E-mail to: fredfldyn@yahoo.com Researchers from Department of Microbiology, Faculty of Science, University of Benin City, Nigeria. E-mail to: fredfldyn@yahoo.com 


\section{Resumo}

A qualidade bacteriológica e físico-química de cinco poços (dos seguintes pontos, Ikoyi, Newton, Iyobosa, Embaixada e Amega) no vilarejo de Ekosodin foi examinada quinzenalmente, de março de 2004 a julho de 2004. A análise bacteriológica mostrou baixa contagem total de bactérias heterotróficas e de bactérias potencialmente patogênicas ao homem, que variou de $1,0 \times 10^{1} \mathrm{cfu} / \mathrm{mI}$ a $3,1 \times 10^{1} \mathrm{cfu} / \mathrm{mI}$, e $0,0-1,9 \times 10^{1}$ $\mathrm{cfu} / \mathrm{mI}$, respectivamente. O total de coliformes variou de 0,00MPN/100mI a 9MPN/100mI. E coli ocorreu ocasionalmente nas estações 2, 3 e 5 com uma variação de 0,00MPN/100mI a 4MPN/100mI. Streptococcus faecalis foi observado somente na estação 3, Clostridium perfringens não foi encontrado em nenhuma das estações analisadas. Outros organismos isolados e caracterizados durante o estudo incluíram Staphylococcus aureus e Proteus sp. Alguns dos parâmetros físico-químicos estudados foram a temperatura da água, a condutividade, o pH, o total de sólidos suspensos e o total de sólidos dissolvidos. As variações respectivas foram de $27^{\circ} \mathrm{C}$ a $28^{\circ} \mathrm{C}$; 9,2 a 13,6 us/cm, 6,4 e 6,7; 0,06 a 0,08 mg/l, e 0,15 a 0,20 mg/l. A demanda biológica de oxigênio (DBO), oxigênio dissolvido (OD), alcanilidade total e o resíduo total em $\mathrm{mg} / \mathrm{l}$ foram todos baixos e variaram de $0,08 \mathrm{mg} / 1$ a $0,2 \mathrm{mg} / 1 ; 0,7 \mathrm{mg} / 1$ a $1,0 \mathrm{mg} / 1 ; 5,0 \mathrm{mg} / 1$ a $6,0 \mathrm{mg} / 1 \mathrm{e} \mathrm{0,10} \mathrm{mg/1} \mathrm{a} \mathrm{0,13mg/}$ 1, respectivamente. Outros parâmetros de baixa concentração foram nitrato $(0,05$ a $0,11 \mathrm{mg} / 1)$, sulfato $(0,07$ $\mathrm{mg} / 1$ a $0,13 \mathrm{mg} / \mathrm{l})$ e fosfato $(0,0 \mathrm{mg} / 1$ a $0,10 \mathrm{mg} / \mathrm{l})$. Todos os parâmetros físico-químicos considerados não indicaram possibilidade de poluição físico-química, já que todos se encaixaram nos níveis máximos permitidos para água potável preconizados pela organização mundial de saúde (OMS). Houve correlação tanto positiva quanto negativa entre as propriedades bacteriológicas e físico-químicas ( $\mathrm{p}=95 \%)$. Baseados nos parâmetros bacteriológicos e físico-químicos estudados, os poços 1 e 4 são próprios para consumo direto, enquanto que os poços 2, 3 e 5 não atingiram o padrão bacteriológico para água potável, portanto não sendo recomendável o consumo de água dos poços destas áreas.

Palavras-chave: Qualidade bacteriológica e físico-química; Ekosodin; E. coli; Streptococcus faecalis; Staphylococcus aureus; Poços de água.

\section{Introduction}

Ekosodin village is in Ovia North East Local Government Area in Edo State Nigeria. The village is mostly populated by students of University of Benin, the indigenes are mostly peasant farmers and petty traders. The main source of water in the village is underground water (boreholes). These bore holes are located in different areas in the village, and are used for both private and commercial purposes to meet with the daily demand for water by the ever increasing population of the University of Benin students, that makes up the greater percentage of the people in the village. Water is literally the "stuff of life". It is very important to life and its use depends on its quality.

Human body is made up of about $65 \%$ of water by weight and water constitutes the medium for many body processes. Human plasma is about $90 \%$ water. Water is the fluid medium in which the protoplasmic masses are suspended as well as the solvent in which various chemical reactions necessary for the maintenance of life takes place, it is the second important substance that sustains life after oxygen. Water is used for domestic activities such as cooking, washing, and drinking. It is useful for other purpose such as transportation, power generation, processing, manufacturing, petroleum exploration and refining, food production and irrigation in agriculture (1). Water supply for human need is obtained from surface water (rivers, streams, lakes) and groundwater. Water on earth occurs in liquid, solid and gaseous forms. The total volume of water is estimated to be about $1.4 \times 10^{14}$ cubic meters or $0.014 \%$, while the ground water is about $8.5 \mathrm{x}$ $10^{15}$ cubic maters or $0.625 \%$. Water in the atmosphere, glaciers and oceans, makes up about $1.33 \times 10^{17}$ cubic meter, which are about 99.255 of the total volume of water on earth (2). The yearly increase population of University of Benin students and the inability of the School to accommodate all her students led to increased population of students in Ekosodin village. This in turn put lots of pressure on the available constant water and therefore creates scarcity of portable water in the village. Hence the increase in the numbers of boreholes, to meet the water need of the village. The sanitary quality of drinking water is determined primarily by the kind of microorganisms present rather than the numbers. $(3,4)$. A source of water is considered bacteriological portable if it does not contain any 
microorganism that may be pathogenic to man. That is, portable water should be free from pathogenic microorganisms (4). The routine monitoring for these pathogenic microorganism, which causes gastrointestinal diseases such as cholera, typhoid, and dysentery are impractical (difficult to detect) and expensive. Instead the analyst must be satisfied with the indirect evidence of the presence of pathogens by testing for indicator organism such as coliform microorganisms (5).

Majority of the boreholes are drilled by amateurs and without observing the safe distance of $50 \mathrm{ft}$ between borehole and septic tanks of the hostels, therefore increasing the chances of polluting the groundwater due to increase human activities. The daily intake of water from these boreholes without knowing its quality necessitated this research work, with a view to finding the bacteriological and physicochemical quality of some of these boreholes water used commercially in the village.

\section{Materials and methods}

\section{Sample collection}

Five (5) different boreholes (stations) (Ikoyi's lodge, Newton's Villa, Iyobosa Hostel, Embassy Hostel and Amega Villa) in Ekosodin village, Benin City were used for the examination. The water samples from each of the boreholes were collected from the boreholes storage tank (tap), the storage tank tap was opened and allowed to flow for $5 \mathrm{~min}$. before the collection. The samples for the bacteriological analysis were collected in pre-sterilized $250 \mathrm{ml}$ sample bottles with glass stoppers. Samples for dissolved oxygen (DO) and biochemical oxygen demand (BOD) were collected in $250 \mathrm{ml}$ reagent bottles with stoppers. The oxygen was fixed on site by the addition of $1.2 \mathrm{ml}$ each of Winkler's solution A and B. Samples for other physicochemical analysis were collected in 2-liter plastic containers previously washed, rinsed and dried in the laboratory. All samples were transported in an iced packed box (cooler) to the laboratory for analysis, those that could not be treated immediately were stored in the refrigerator at a temperature of $4^{\circ} \mathrm{C}$. Samples were collected fortnightly from March 2004 to July 2004.

\section{Bacteriological and physicochemical analyses}

The Bacteriological analyses were carried out in accordance with Bergey's Manual of Determinative Bacteriology $(6,7)$. The bacteriological parameters investigated includes, total plate count to determine the total bacterial in the sample, detection and estimation of the coliform organisms and E. coli, detection and estimation of faecal Streptococci, detection and the estimation of Clostridium perfringens and detection of potential human pathogens. The physicochemical parameters studies were $\mathrm{pH}$, water temperature, conductivity, turbidity, total dissolved solids, total suspended solids, total solids, chemical oxygen demand, dissolved oxygen, biological oxygen demand, total alkalinity, nitrate, phosphate, calcium, magnesium and total hardness. The physicochemical parameters were studied in accordance with the standard methods of APHA (8).

\section{Results}

Results obtained fortnightly (March - July 2004) from the five sampled stations (Ikoyi, Newton's, Iyobosa, Embassy and Amega boreholes) did not show much variance within stations and among the different stations. It showed generally low total viable bacterial counts. The population range of bacteria obtained from the boreholes is given in Table 1. The total heterotrophic bacterial counts in all the sampled stations ranged from 1.0 $\times 10^{1} \mathrm{cfu} / \mathrm{ml}$ to $3.1 \times 10^{1} \mathrm{cfu} / \mathrm{ml}$. The highest count $\left(3.1 \times 10^{1} \mathrm{cfu} / \mathrm{ml}\right)$ was recorded in May and July at Iyobosa and Embassy (station 3 and 4). The potential human pathogenic bacterial counts ranged from 0.0 to $1.9 \times 10^{1} \mathrm{cfu} / \mathrm{ml}$. The highest value of $1.9 \times 10^{1} \mathrm{cfu} / \mathrm{ml}$ was obtained in July at Iyobosa (station 3). In all the stations total heterotrophic and potential human pathogenic bacterial counts did not follow any consistent pattern.

Coliform organisms were found in all the sampled stations. A population range of 0.0 MPN/ $100 \mathrm{ml}-9.0 \mathrm{MPN} / 100 \mathrm{ml}$ was recorded for total coliforms in all the stations. The highest value (9.0 MPN/100ml) was recorded at station 3 in June. No coliform was recorded in July for station 1, March and May in station 2, March, June and July for station 4 and in the months of March and June in 
station 5. The total coliform counts were seen to fluctuate in all the stations throughout the study period. As the rainy season set in, May - June, the total coliform counts increased.

$E$. coli counts in all the stations were relatively low, as it was detected only occasionally in three of the five station sampled (2, 3, and 5) (Table 1 ). Total $E$. coli counts ranged from $0.00 \mathrm{MPN} / 100 \mathrm{ml}$ to $4.0 \mathrm{MPN} / 100 \mathrm{ml}$. The highest count of $4.0 \mathrm{MPN} / 100 \mathrm{ml}$ was recorded at stations 2, in July, stations 3 and 5 in May. E. coli counts also increased in the rainy months May-July. Streptococci were recorded only in station 3 (Iyobosa). A total count of $3.0 \mathrm{MPN} /$ $100 \mathrm{ml}$ was recorded in the months of May, June and July, the peak of rainy season. Clostridium was not detected in all the sampled stations. Organisms isolated were Staphylococcus aureus, E. coil, Streptococcus faecalis, and Proteus sp. The occurrence and distribution of the bacterial isolates is shown in Table 2. Table 3 showed the results of the physicochemical parameters investigated. The water samples were clear, odourless and tasteless throughout the study period. All the physicochemical parameters considered did not indicate any possible physicochemical pollution as they fell within the 9 maximum permissible level for portable water. There were both positive and negative correlations between some of the bacteriological and physicochemical properties at a significant level of $95.5 \%$ probability limit.

\section{TABLE 1 - Population range of bacterial isolates from the sampled stations}

\begin{tabular}{|c|c|c|c|c|c|c|}
\hline 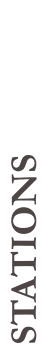 & 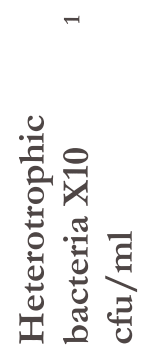 & 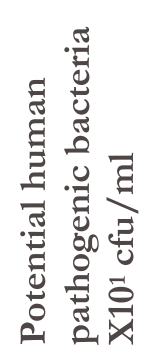 & 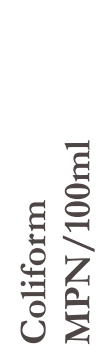 & 音 & 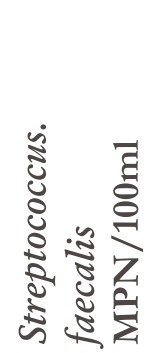 & 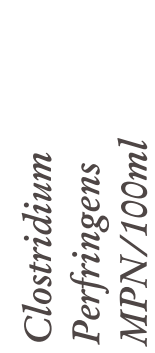 \\
\hline 1 & $2.0-2.8$ & $0-1.8$ & $0-4$ & 0 & 0 & 0 \\
\hline 2. & $1.5-2.1$ & $0-1.5$ & $0-7$ & $0-4$ & 0 & 0 \\
\hline 3. & $2.2-3.1$ & $1.0-1.9$ & $0-9$ & $0-4$ & $0-3$ & 0 \\
\hline 4. & $1.0-2.0$ & $0-1.3$ & $0-3$ & 0 & 0 & 0 \\
\hline 5. & $2.4-3.0$ & $0-1.6$ & $0-7$ & $0-4$ & 0 & 0 \\
\hline
\end{tabular}


Bacteriological and physicochemical quality of some water boreholes in Ekosodin, Benin city, Nigeria

TABLE 2 - Occurrence and distribution of bacterial isolates in the sampled stations

\begin{tabular}{|c|c|c|c|c|c|c|c|c|c|c|c|c|c|c|c|c|c|c|c|c|}
\hline MONT & \multicolumn{4}{|c|}{ STATION 1} & \multicolumn{4}{|c|}{ STATION 2} & \multicolumn{4}{|c|}{ STATION 3} & \multicolumn{4}{|c|}{ STATION 4} & \multicolumn{4}{|c|}{ STATION 5} \\
\hline & 1 & 2 & 3 & 4 & 1 & 2 & 3 & 4 & 1 & 2 & 3 & 4 & 1 & 2 & 3 & 4 & 1 & 2 & 3 & 4 \\
\hline MARCH & + & + & - & - & + & + & - & - & + & - & + & - & + & - & - & - & + & + & - & - \\
\hline & - & - & - & - & + & - & - & - & + & - & - & - & - & + & - & - & + & + & - & - \\
\hline APRIL & + & + & - & - & + & - & + & - & + & + & - & - & - & - & - & - & + & - & - & - \\
\hline & + & + & - & - & + & + & + & - & + & + & - & - & + & + & - & - & + & - & + & - \\
\hline MAY & + & + & - & - & + & - & - & - & + & + & + & + & + & + & - & - & + & - & - & - \\
\hline & + & - & - & - & + & + & - & - & + & + & - & - & + & - & - & - & + & + & + & - \\
\hline JUNE & + & - & - & - & + & + & + & - & + & - & + & + & + & + & - & - & + & + & - & - \\
\hline & + & + & - & - & + & - & - & - & + & + & - & + & + & - & - & - & + & - & + & - \\
\hline JULY & + & + & - & - & + & + & + & - & + & + & - & - & + & - & - & - & + & + & + & - \\
\hline & + & + & - & - & + & - & + & - & + & - & + & + & + & + & - & - & + & - & - & - \\
\hline
\end{tabular}

NB: 1 = Staph. aureus 3. E.coli $; 2=$ Proteus sp. $\quad$ 4. Strept. faecalis ; + = Present ; $\quad-=$ Absent.

TABLE 3 - Summary of the physicochemical parameters

\begin{tabular}{|l|l|l|l|l|l|l|}
\hline PARAMETERS & NO & STATION 1 & STATION 2 & STATION 3 & STATION 4 & STATION 5 \\
\hline PH & 10 & 6.4 & 6.4 & 6.7 & 6.5 & 6.5 \\
WATER TEMPT. ${ }^{\circ}$ C & 10 & 28.0 & 27.4 & 27.0 & 27.2 & 27.6 \\
ATM. TEMPT. ${ }^{\circ}$ C & 10 & 28.2 & 28.0 & 28.2 & 27.8 & 28.3 \\
CONDUCTIVITY & 10 & 11.1 & 9.2 & 13.6 & 9.5 & 10.8 \\
US/CM & & & & & & \\
TSS mg/I & 10 & 0.08 & 0.07 & 0.06 & 0.08 & 0.07 \\
TDS mg/I & 10 & 0.20 & 0.20 & 0.15 & 0.18 & 0.20 \\
TS mg/I & 10 & 0.27 & 0.24 & 0.21 & 0.26 & 0.25 \\
DO & 10 & 1.0 & 1.0 & 0.7 & 0.9 & 1.0 \\
BOD mg/I & 10 & 0.1 & 0.08 & 0.2 & 0.1 & 0.1 \\
NITRATE mg/I & 10 & 0.10 & 0.10 & 0.04 & 0.05 & 0.05 \\
PHOSPHATE mg/I & 10 & 0.10 & 0.06 & 0.04 & 0.10 & 0.06 \\
SULPHATE mg/I & 10 & 0.10 & 0.11 & 0.07 & 0.10 & 0.13 \\
HARDNESS mg/I & 10 & 0.10 & 0.13 & 0.10 & 0.10 & 0.10 \\
ALKALINITY mg/I & 10 & 5.0 & 6.0 & 5.0 & 5.5 & 5.1 \\
IRON mg/I & 10 & 0.02 & 0.01 & 0.01 & 0.02 & 0.01 \\
ZINC mg/I & 10 & 0.05 & 0.05 & 0.03 & 0.1 & 0.05 \\
MANGANESE mg/I & 10 & 0.03 & 0.02 & 0.02 & 0.05 & 0.01 \\
\hline
\end{tabular}




\section{Discussion}

Low bacterial counts were obtained from all sampled boreholes in Ekosodin village from March 2004 to July 2004. The total bacterial counts ranged from 1.0 to $3.1 \times 10^{\circ} \mathrm{cfu} / \mathrm{mI}$, which is within standard for portable water (9). This count is similar to those obtained by Ejechi, (10) that reported a range of 0 to 173 organisms in Ugbowo groundwater, and differs from that of Fepazeri Center (11), that studied the impact of agrochemicals on different communities in Bauchi State which reported total bacterial counts of $1.0 \mathrm{x}$ $10^{6} \mathrm{cfu} / \mathrm{ml}$ to $2.0 \times 10^{6} \mathrm{cfu} / \mathrm{mI}$. The presence of coliform alone in stations 1 and 4 is indicative of possible non-faecal pollution of water. And this finding is in agreement with that of Holden et al. (12) that observed only coliform in some wells in their well water survey. The non-detection of the notable faecal pollution indicators, Escherichia coli, Streptococcus faecalis regularly throughout the period of this research, makes faecal pollution unlikely. This suggests the fact that total bacteria and coliform detected could have been from the soil surface. Geidreich (4) noted that coliform could originate from non-faecal sources such as plants and soils.

The detection of E. coli and S. facalis in station 3 (Iyobosa) may be attributed to a possible faecal pollution of human or animals. These organisms were observed more in the rainy months of May through July. Several factors may be adduced to the differences in microbial counts and types of organisms observed in station 3 (Iyobosa). These include floodwater that flows through the street and some flow into station 3 (Iyobosa) whenever it rains. Secondly pipes that convey water from the boreholes to the storage tanks run at a point close to pipes conveying water from bathrooms and kitchen to the septic tank. This view is in agreement with the findings of Alan (13), William (14), and Osime (15) that plastic pipes under such circumstances could permit organisms to pass through its walls and contaminate the conveyed water. Other organisms isolated from the sampled stations were Staphylococcus sp., and Proteus sp., which are normal flora of soil, and could have been washed in from soil or from storage tank. All of the physicochemical parameters measured in the sampled water (boreholes) fell within the recommended permissible limits for potable water (9). The water temperature was lower than the atmospheric temperature and it ranged from $26.0^{\circ} \mathrm{C}$ to $29.8^{\circ} \mathrm{C}$. There were no significant fluctuations within stations. This near constancy observed in water temperature is in contrast to fluctuations in surface water as was observed by Benka-Coker Ohimian (16). The $\mathrm{pH}$ values of the sampled stations were all low and within the maximum acceptable standards $(9,2)$ for drinking water (9). This low pH encouraged the growth of organisms observed in the sampled station. Baedecker et al. (17) also observed low $\mathrm{pH}$ in ground water, and attributed this to lack of calcareous or other soluble materials in the aquifer.

The water from all the boreholes was soft, and showed no colour, odour, or taste. This was due to the absence of materials such as organic matter accumulation, solids or silts that could have been removed during percolation, by filtration and adsorption, as was observed by Burmaster (18). The absence of these organic matters was responsible for the low biochemical oxygen demand (BOD) obtained in all the stations. The mean concentrations of phosphate and sulphate obtained in all the stations were low and within permissible level (9). The nitrate concentration was relatively low with the highest mean concentration of $0.11 \mathrm{mg} / \mathrm{l}$ observed in station 3 (Iyobosa borehole), like other parameters, the nitrate level fell within the maximum allowable limit of $10 \mathrm{mg} /$ 1 for drinking water (9). Water is an integral part of human life, portable water is therefore required to be devoid of pathogenic organisms and chemical contaminants. This study revealed that there is no chemical pollution/contaminants in Ekosodin ground water, as all the five (5) boreholes studied, were within recommended/acceptable limits of physicochemical parameters for portable water (9). The non-detection of specific indicator organisms (E. coli \& Streptococcus faecalis,) in boreholes 1 and 4 (Ikoyi and Embassy) indicates the absence of pathogenic organisms in these boreholes. On the other hand, the occasional detection of E. coli in boreholes 2 (Newton), 3 (Iyobosa) and $S$. faecalis in station 5 (Amega) indicates possible contamination of these boreholes by human or animal faecal matter. It is therefore, recommended that water from this boreholes 2, 3, and 5 (Newtons, Iyobosa and Amega) should be boiled and cooled before consumption $(19,20)$. Pipes (PVC) used in conveying water from these boreholes should be 
checked for breakage, replaced and separated from those conveying wastewater from bathrooms and kitchens. The pipes should be deep in the soil and not visible while storage tanks should be washed regularly to remove biofilms and old broken ones are changed.

\section{References}

1. International Development Research Center. Fresh water. The human imperative. Ottawa; 1988. $40 \mathrm{p}$.

2. Moran JM, Morgan MD, Wiersma, JH. Introduction to Environmental Science. San Francisco: Freeman and Co; 1972. 261 p.

3. Atlas RM, Bartha R. Microbial Ecology: Fundamentals and Application. New York: Benjamin/Cummings Co; 1993. 63 p.

4. Geldreich, EE. Microbiological quality of source water for water supply. In: McFfeters GA. editor. Drinking Water Microbiology. Berlin: Springer Verlag; 1990. 443p.

5. Francy DS, Myers ND, Metzer DK. Escherichia coli and faecal coliform bacteria as indicator of recreational water quality. Ohio water resources investigation report. 1993; 93:4083.

6. Buchanan RE, Gibbon NE. Bergey's Manual of Determinative Bacteriology. $8^{\text {th }}$ ed. Baltimore: Williams and Wilken Co; 1974. 3100 p.

7. Gerhardt P, Murray EGR, Wood AW, Krieg RN. Methods for General and Molecular Bacteriology. Washington: ASM. Press; 1994. 791 p.

8. American Public Health Association (APHA). Standard methods for the examination of water and wastewater. $18^{\text {th }}$ ed. Washington: APHA; 1993. $1334 \mathrm{p}$.

9. World Health Organization. International standard for water quality. Geneva: WHO; 1996. $46 \mathrm{p}$.

10. Ejechi BO. Microbiological and physicochemical assessment of the quality of University of Benin Ugbowo Campus Groundwater supply. Benin City, Nigeria: M.Sc Thesis University of Benin; 1985. $78 \mathrm{p}$.
11. Fepazaeri Center. The impact of agrochemical on eight-selected local government of Bauchi State. Bauchi: Abubakar Tafawa Balewa University; 2000. 31 p.

12. Holden LR, Graham JA, Whitemore RW, Alexander WJ, Pratt RW, Liddle SK, Piper LL. Results of the national Alachlor well survey. Environ Sci Technol. 1992; 26:935-943.

13. Alan RB. Perdition of organic chemical permeation through PVC pipe. J Ameri W W Assoc. 1985; 77:11-57.

14. William GL. Water contamination caused by gasoline permeating a polybutylene pipe. J Ameri W W Assoc. 1996; 78:11-39.

15. Osime, O. E. Bacteriological and physicochemical quality of water conveyed by asbestos, iron and polyvinylchloride pipes. Benin City, Nigeria: M Sc. University of Benin; 2001. 87 p.

16. Benka-Coker MO, Ohimian, EI. Investigation spatial variations in bacteria distribution in surface waters of Ikpoba River. Nig J Microbiol. 1995; 10:27-32.

17. Baedecker M, Back W. Hdrogelogical processes and chemical reactions at landfill. Groundwater. 1979; 17:429-437.

18. Burmaster DE. The new pollution: Groundwater contamination problem. Environment. 1982; 2: 7-36.

19. Center for Disease Control and Prevention (CDCP). Addressing Emerging Disease Threats. Atlanta, USA: A strategy for the United States; [19--?]. 102 p.

20. Rheinheimer G. Aquatic Microbiology. $4^{\text {nd }} e d$. New York: John Wiley and Sons; 1991. 363 p.

Recebido em: 12.01.2006 Aceito em: 21.02.2006 